\title{
Voles Can Improve Sagebrush Rangelands ${ }^{1}$
}

\section{NEIL C. FRISCHKNECHT ${ }^{2}$ AND MAURICE F. BAKER}

Range Scientist, Intermountain Forest and Range Experiment Station, Forest Service, U.S. Department of Agriculture, Ogden, Utah; and Wildlife Biologist, Bureau of Sport Fisheries and Wildlife, U.S. Department of the Interior, Federal Building, Provo, Utah.

\section{Highlight}

During cyclic population peaks, voles kill and damage sagebrush and other shrub species over large areas. Damage is greatest when a dense, ungrazed herbaceous understory exists and when the snowpack persists throughout the winter. If peaks in population could be predicted, grazing should be managed to leave all possible herbaceous cover on areas where killing of brush is desired; conversely, grazing by cattle should be heavy where perpetuation of shrubs is preferred.

In the spring of 1969 , we observed that voles had killed and damaged big sagebrush (Artemisia tridentata Nutt.) over sizable areas in Utah and Nevada during the previous winter. Phillips (1970) reported extensive damage by voles to big sagebrush in southern Idaho during the same period. Earlier, Mueggler (1967) observed a similar situation in Montana.

In this paper, we report results of sampling eight areas in southeastern Tooele County, Utah, in July 1969, to determine the amount of brush killed and the species of vole present. Range managers might take advantage of peak vole populations to improve ranges infested with big sagebrush, and precautions may be taken to

1 Received for publication November $1,1971$.

${ }^{2}$ Stationed in Provo, Utah, Office, which is maintained in cooperation with Brigham Young University. deter damage where shrubs are desired.

Areas sampled ranged from 6,500 to 7,500 feet elevation; little damage was noted below 6,500 feet elevation. Average annual precipitation is estimated to range from 15 to 20 inches and about $60 \%$ falls as snow on the study areas. Study areas were in five different drainages that were snow-covered throughout the winter. By spring, many sagebrush stems had been girdled as high as the snow was deep-up to 20 inches on some areas. Brush plants were counted on a transect of 10 plots per area and judged as to whether they were undamaged or completely or partly killed by voles or by other factors. Plots were circular, 100 square feet in size, and spaced 30 yards apart. Species of rodents present on the study areas were determined by one night's trapping with two snap traps placed on each of the 80 plots.

Twenty-three longtailed voles (Microtus longicaudus latus Hall) and 20 deer mice (Peromyscus maniculatus sonoriensis Le Conte) were captured in 160 trap nights. Deer mice were uniformly distributed among the samples, but voles, which were present on all areas, were caught more commonly in samples from higher elevations. Although trapping followed the heavy brush kill, we are certain that the longtailed vole was the principal species involved in girdling of brush; deer mice are not known to eat bark.

Voles eat the cambium layer of sagebrush; in so doing they strip bark from plants and girdle stems and branches. Overall, an average of $59 \%$ of the big sagebrush plants were completely killed by voles and an additional 28\% showed some damage (Table 1). Greatest kill of sagebrush was in draws and low places that had a dense cover of grass. These areas receive extra moisture, especially in the form of snow. Where present, tall cheatgrass brome (Bromus tectorum L.) was particularly favorable $\mathrm{mi}$ crotine habitat. The most prominent perennial grasses were thickspike wheatgrass [Agropyron dasystachyum (Hook.) Scribn.] and bluebunch wheatgrass [A. spicatum (Pursh) Scribn. and Smith].

Mueggler (1967) also observed that the greatest damage to sagebrush occurred in lush, productive spots where snowfall had been continuous throughout the winter. Phillips (1970) reported that toe slopes and canyon rims showed greater damage than canyon slopes and ridgetops.

Apparently a good herbaceous cover is conducive to buildup of high populations of voles, inasmuch as they form their runways through the litter on top of the ground. The second feature related to extensive brush kill is a snow cover that persists through the winter of a high vole density.

Of particular interest were two sizable areas, each several hundred acres in size, that were ungrazed by livestock in 1968. One area was privatc range, purchascd and fenced by Wolf Brothers of Goshen, Utah, in the spring of 
Table 1. Damage (\%) to big sagebrush on areas of various brush densities following an irruption of longtailed voles, Tooele County, Utah.

\begin{tabular}{|c|c|c|c|c|c|}
\hline \multirow[b]{2}{*}{ Area } & \multirow{2}{*}{$\begin{array}{c}\text { Brush } \\
\text { density }\end{array}$} & \multicolumn{2}{|c|}{ Brush girdled by voles } & \multirow{2}{*}{$\begin{array}{c}\text { Brush } \\
\text { previously }_{\text {killed }^{2}}\end{array}$} & \multirow{2}{*}{$\begin{array}{l}\text { Undamaged } \\
\text { brush }\end{array}$} \\
\hline & & Dead & Damaged & & \\
\hline \multicolumn{6}{|l|}{ Vernon Canyon } \\
\hline Slope 1 & 14.4 & 36 & 35 & 12 & 17 \\
\hline Slope 2 & 7.5 & 57 & 31 & 11 & 1 \\
\hline Bottom 1 & 4.4 & 64 & 23 & 13 & 0 \\
\hline Bottom 2 & 6.5 & 65 & 20 & 15 & 0 \\
\hline Harker Canyon & 4.6 & 63 & 24 & 11 & 2 \\
\hline Bennion Canyon & 3.7 & 73 & 27 & 0 & 0 \\
\hline Snow Hollow & 7.2 & 60 & 35 & 17 & 3 \\
\hline Little Valley & 5.4 & 56 & 26 & 12 & 6 \\
\hline
\end{tabular}

${ }^{1}$ Number $/ 100 \mathrm{ft}^{2}$.

${ }^{2}$ Causes not known.

1968. Owners were highly elated the following year because voles had killed most of the big sagebrush, thereby boosting yields of herbaceous species (Fig. 1). Longtailed voles appeared to select plants that also showed evidence of insect damage in the form of twig galls. However, this was a general observation and we have no specific information on this point.

The other area was part of a cattle allotment, protected from grazing by the Wasatch National Forest in connection with a juniper [Juniperus osteosperma (Torr.) Little] chaining and seeding project. Much sagebrush on the untreated slopes was killed by voles. This saved a considerable sum of money that was to have been used in a spraying project to kill brush.

Although big sagebrush was

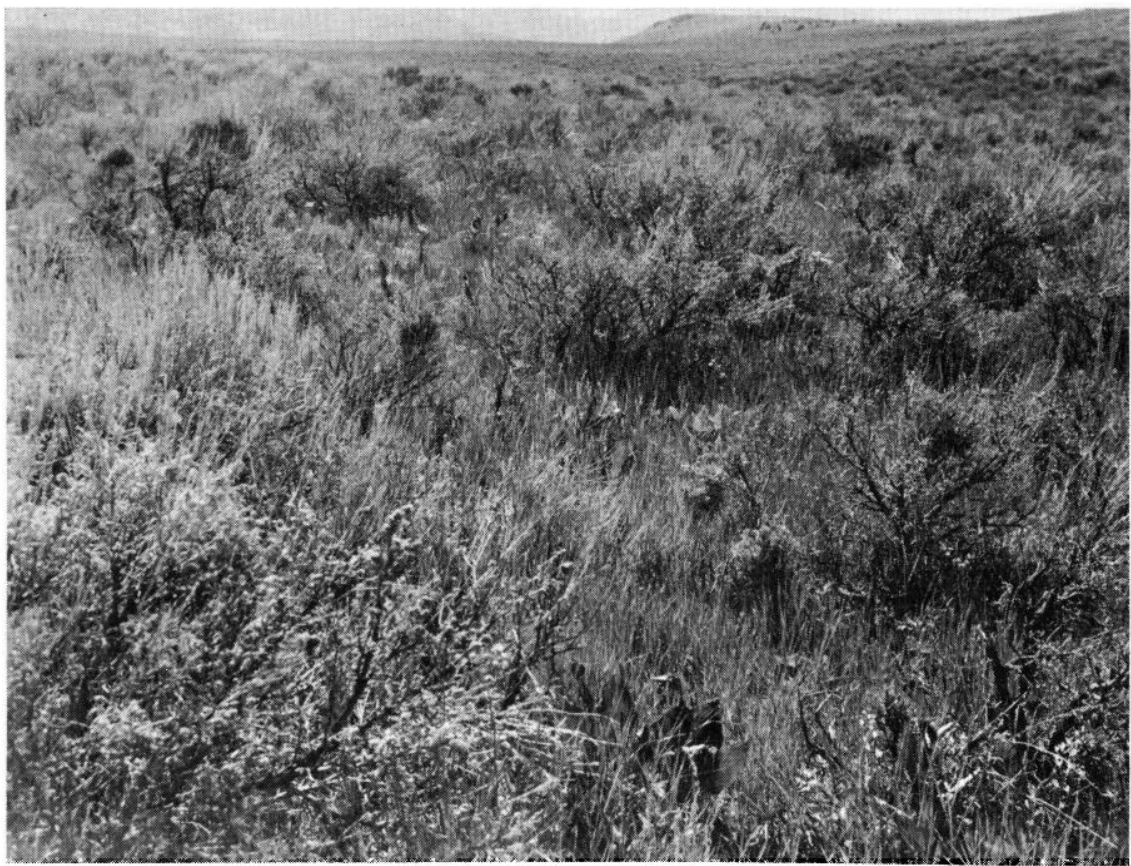

FIG. 1. Dense herbaceous understory prevails where sagebrush was killed by voles the previous winter. most seriously affected, girdling was also observed on associated rubber rabbitbrush [Chrysothamnus nauseosus (Pall.) Britton] and yellowbrush $[C$. viscidiflorus (Hook.) Nutt.]. Rubber rabbitbrush occurred only in the canyon bottoms; yellowbrush was more ubiquitous. In Vernon Canyon bottoms, there were approximately as many rabbitbrush plants as sagebrush. Up to one-half of the rabbitbrush plants were killed completely and most of those surviving showed evidence of vole damage. An average of three yellowbrush plants per $100 \mathrm{ft}^{2}$ were distributed over the study area. Few yellowbrush plants were completely killed and about one-half of them showed no damage whatsoever.

In some draws on north slopes where sagebrush was limited, voles girdled little snowberry (Symphoricarpos oreophilus A. Gray), Saskatoon serviceberry (Amelanchier alnifolia Nutt.) and western chokecherry [Prunus melanocarpa (A. Nels.) Rydb.]. Since these species were not on our transects, no attempt was made to determine the extent of damage on them, but many stems of all three species were killed. We observed no permanent damage to herbaceous plants.

In addition to the 1968 irruption of longtailed voles, Phillips (1970) reported that irruptions in 1958 and 1963 caused extensive damage to bitterbrush [Purshia tridentata (Pursh) DC.] in southern Idaho. The 1963 irruption in southern Idaho coincided with both the irruption reported by Mueggler (1967) in Montana and that reported by Smith (1969) in the Wasatch Mountains of Utah in the winter of 1963-64. The latter irruption caused heavy damage to red elderberry (Sambucus racemosa L.) between 7,500 and 9,000 feet elevation.

Since microtine population numbers are known to be cyclic, high points in cycles probably could be predicted by frequent small mam- 
mal censuses. In our study, however, the noticeable irruption occurred during the growing season immediately preceding the heavy damage to brush in the winter of 1968-69. Trapping during the previous 2 years in the samc general area did not reflect a gradual buildup in microtine numbers (Black and Frischknecht, 1971). In addition to censusing, a better understanding of the factor or factors that trigger irruptions would be highly valuable.

Predictions of irruptions would be of great importance to grazing management programs. During an irruption, microtine populations can be expected to be highest in areas where considerable grass is left on the ground. Other things being equal, such areas are likely to be ungrazed or lightly grazed as under a rest-rotation system of management. Preliminary evidence suggests that the peaks in microtine population cycles are 4 or 5 years apart. Range managers should be aware that population pcaks could coincide with a grazing cycle that rests a given unit from grazing every 4 or 5 years. Grazing could be manipulated so that areas on which brush control is needed are not grazed in years of vole irruptions to allow buildup of herbaceous cover for voles. On the other hand, areas on which shrubs are desired should be grazed well in those years to reduce herbaceous cover. This study demonstrates the complexities of range ecosystems and the need for understanding interactions of the components.

\section{Literature Cited}

Black, Hal L., and Neil C. FrischKNECHT. 1971. Relative abundance of mice on seeded sagebrush-grass range in relation to grazing. USDA Forest Serv. Res. Note INT-147, 8 p. Intcrmountain Forest and Rangc Exp. Sta., Ogden, Utah.

Mueggler, W. F. 1967. Voles damage big sagebrush in southwestern Montana. J. Range Manage. 20:8890.

Phillips, T. A. 1970. The status of antelope bitterbrush in the Cassia mountain area of southern Idaho. Forest Service, U.S. Dep. Agr., Intermountain Region, Range Impr. Notes 15(4):1-15.

Sмiтн, H. D. 1969. Small mammal populations and bioenergetics in the Wasatch mountains, Utah. Ph.D. diss., Univ. Ill., Urbana. 